\title{
POTENSI PEMANFAATAN LAHAN RAWA UNTUK MENDUKUNG PEMBANGUNAN PERTANIAN DI WILAYAH PERBATASAN
}

\section{POTENTIAL FOR THE UTILIZATION OF SWAMP LANDS TO SUPPORT AGRICULTURAL DEVELOPMENT IN BORDER AREAS}

\author{
Niken Rani Wandansari ${ }^{1}$, Yeni Pramita ${ }^{2}$ \\ ${ }^{1}$ Staf Pengajar Politeknik Pembangunan Pertanian Malang \\ ${ }^{2}$ Mahasiswa Politeknik Pembangunan Pertanian Malang \\ e-mail: wandansari.niken@gmail.com, riskayeni18@gmail.com
}

\begin{abstract}
ABSTRAK
Pemanfaatan lahan rawa di Indonesia memiliki peranan penting dan strategis bagi pengembangan pertanian terutama mendukung ketahanan pangan Nasional. Hal ini disebabkan oleh luas lahan rawa yang berpotensi untuk dijadikan lahan pertanian khususnya tanaman padi masih tersedia cukup luas. Lahan rawa merupakan salah satu lahan suboptimal yang memiliki kendala secara alami kesuburan tanahnya tergolong rendah. Oleh karena itu penting dilakukan pengkajian untuk mengetahui potensi pemanfaatan lahan rawa di Kab. Lingga, Kepulauan Riau untuk digunakan sebagai lahan pertanian padi sawah. Kajian ini merupakan action research menggunakan lahan seluas tiga hektar sebagai demplot pertanaman padi yang terletak di tiga kecamatan utama di Pulau Lingga. Berdasarkan hasil kajian, diketahui bahwa: (1) kendala utama pengembangan lahan rawa lebak adalah genangan maupun kekeringan yang belum dapat diprediksi dan reaksi tanah yang bersifat sangat masam-masam, serta status hara yang tergolong rendah-sedang dan (2) hasil panen menggunakan varietas INPARA 5 masih tergolong rendah, sekitar 0.5 - 2.5 ton/ha. Produksi padi pada lahan rawa lebak masih berpeluang untuk dikembangkan dan ditingkatkan dengan melalui penerapan teknologi spesifik lokasi, terutama inovasi pengelolaan air, hara dan tanaman secara terpadu, serta dilakukan pembentukan kelembagaan petani.
\end{abstract}

Kata kunci-lahan rawa, padi sawah, produktivitas

\begin{abstract}
The potential for the utilization of swamp lands in Indonesia has an important and strategic role for the development of agriculture, especially in supporting National food security. This is due to the vast swamp land that has the potential to be used as agricultural land, especially paddy soil. Swamp land is one of the suboptimal land which has naturally low soil fertility constraints. Therefore, it is important to study to determine the potential utilization of swamps in the Lingga Regency, Riau Islands to be used as wetland paddy fields. This study is an action research. Based on the results of the study, it is known that: (1) the main obstacles to developing swamps are unpredictable inundation and drought, alsoacidic soil reactions and low nutrient status, and (2) the yields using rice varieties of INPARA 5 is still relatively low, around 0.5-2.5 tons/ha. Rice production in swamp swamp land still has the opportunity to be developed
\end{abstract}


and improved through the application of location-specific technologies, especially innovations in integrated water, nutrient and plant management, and the establishment of farmer institutions.

Keywords — swamp land, paddy soil, productivity

\section{PENDAHULUAN}

Kebutuhan pangan Nasional setiap tahunnya mengalami peningkatan secara signifikan seiring dengan peningkatan jumlah penduduk. Pada tahun 2017, jumlah penduduk Indonesia mencapai 262 juta jiwa dengan laju pertumbuhan pertahunnya pada tahun 2010 hingga 2017 mencapai 1,34\% (BPS, 2017).

Dari data tersebut maka Pemerintah berkomitmen untuk mewujudkan kedaulatan pangan di dalam negeri pada tahun 2015 dengan menargetkan produksi padi ditetapkan 73 juta ton GKG, jagung 20 juta ton, dan kedelai 1,2 juta ton (Kurniawan, 2015). Oleh karena itu, dalam upaya mewujudkannya harus diimbangi dengan peningkatan produktivitas dan ketersediaan sumberdaya lahan pertanian agar ketahanan pangan Nasional dapat terpenuhi dan berkelanjutan.

Namun pada kenyataanya, saat ini telah terjadi alih fungsi (konversi) lahan pertanian menjadi non-pertanian, sedangkan upaya perluasan lahan pertanian baru (ekstensifikasi) berjalan relatif lambat terutama pada lahan-lahan sub optimal. Tantangan dan kendala yang dihadapi pada lahan tersebut, umumnya secara alami kesuburan tanahnya tergolong rendah, yang biasanya ditunjukkan oleh tingkat keasaman yang tinggi, ketersediaan hara yang rendah, serta kejenuhan basa-basa dapat dipertukarkan rendah (Suharta, 2010).

Berdasarkan data sumberdaya lahan Indonesia pada skala eksplorasi 1:1.000.000, lahan sub optimal dapat dikelompokkan menjadi empat tipologi lahan, yaitu: lahan kering masam, lahan kering iklim kering, lahan rawa pasang surut, lahan rawa lebak dan lahan gambut (Puslitbangnak, 2000).

67 | Jurnal Agriekstensia Vol. 18 No. 1 Juli 2019
Indonesia memiliki luas daratan mencapai 189.1 juta ha, dan sebagian besar termasuk lahan sub optimal. Terluas berupa lahan kering masam yang dijumpai pada wilayahwilayah yang memiliki curah hujan tinggi (> $2.000 \mathrm{~mm}$ per tahun), sehingga terjadi pencucian hara dan tingkat pelapukan yang intensif di sebagian besar wilayah Indonesia. Kondisi sebaliknya terjadi pada wilayah bagian timur Indonesia, yaitu merupakan wilayah yang beriklim kering dengan curah hujan $<2.000 \mathrm{~mm}$ per tahun, yang luasnya sekitar 45.3 juta ha (Balitklimat, 2003; Mulyani et al., 2013).

Saat ini jumlah lahan rawa luasnya kurang lebih 33.4 juta ha, sekitar 9-14 juta ha di antaranya sesuai untuk pertanian, namun baru 5,27 juta ha yang telah dimanfaatkan (Maftuah et al., 2016). Lahan rawa terdiri atas lahan rawa pasang surut (20.1 juta ha) dan lahan rawa lebak (13.3 juta ha) yang sangat berpotensi untuk dikembangkan sebagai penghasil pangan dan komoditas lainya di Indonesia.

Lahan rawa pasang surut maupun rawa lebak sangat berpotensi sebagai lumbung pangan nasional. Kawasan rawa pasang surut dapat menjadi sumberdaya yang potensial bagi pertumbuhan ekonomi baru terhadap produksi komoditas pertanian, karena mempunyai beberapa keutamaan antara lain: ketersediaan air yang melimpah, topografi relatif datar, akses ke wilayah pengembangan dapat melalui jalur darat dan jalur air sehingga memudahkan jalur distribusi, kepemilikan lahan yang relatif luas sehingga sangat ideal bagi pengembangan usaha tani secara mekanis, serta dengan pengaturan waktu panen saat off season (di luar musim) dapat menjadi solusi dalam mensubstitusi ketersediaan pangan di Pulau Jawa saat tidak ada panen. 
Optimalisasi pemanfaatan lahan rawa sangat perlu dilakukan untuk mewujudkan rawa sebagai lumbung pangan. Lahan rawa merupakan lahan fragile (rapuh), sehingga perlu adanya konservasi yang dilakukan secara serius dengan berbagai inovasi teknologi, seperti: (1) teknologi pengelolaan air dan tanah, meliputi tata kelola air mikro, penataan lahan (lay out), ameliorasi dan pemupukan; (2) varietas unggul baru yang lebih adaptif dan produktif; dan (3) alat dan mesin pertanian yang sesuai untuk tipologi lahan tersebut (Suriadikarta, 2011 dalam Arsyad et al., 2014). Tujuan kajian ini adalah untuk mengetahui potensi pemanfaatan lahan rawa di Kab. Lingga, Kepulauan Riau untuk digunakan sebagai lahan pertanian padi sawah.

\section{METODE PENELITIAN}

Kajian ini merupakan action research menggunakan lahan seluas tiga hektar sebagai demplot pertanaman padi yang terletak di kec. Lingga, kec. Lingga Timur dan kec. Lingga Utara, kabupaten Lingga, Kepulauan Riau. Kajian dilaksanakan mulai bulan Februari hingga Agustus 2018.

Parameter yang dianalisis selama kajian antara lain: (1) karakteristik tanah yang diukur menggunakan alat uji tanah rawa sederhana (PUTR) dan (2) parameter produksi tanaman dengan menghitung bobot gabah kering panen (GKP) ton per hektar.

Data yang diperoleh selanjutnya diperbandingkan dengan metode deskriptif dari data sekunder yang berasal dari hasilhasil penelitian terdahulu terkait pemanfaatan lahan rawa untuk pertanamana padi sawah. Data tersebut kemudian dibahas, serta selanjutnya diambil kesimpulan.

\section{HASIL DAN PEMBAHASAN}

\section{Karakteristik Lokasi Pengkajian}

Kabupaten Lingga terletak di antara $0^{\circ} 20^{\prime}$ LU-0 40 ' LS dan $104^{\circ}-105^{\circ}$ BT. Luas wilayah daratan dan lautan mencapai $45.456,71 \mathrm{~km}^{2}$. Sebagian besar topografinya adalah berbukit-bukit. Kabupaten Lingga mempunyai iklim tropis basah dengan variasi curah hujan rata-rata $264.98 \mathrm{~mm}$ sepanjang tahun 2016. Rata-rata suhu udara menunjukkan variasi antara 26.9-28.0 ${ }^{\circ} \mathrm{C}$, sedangkan rata-rata kelembabannya antara 85- 88 \% (BPS Kab. Lingga, 2017).

Lokasi pengkajian merupakan lahan rawa lebak, yang tergolongan ke dalam lebak dangkal. Hamparan lahan sawah yang digunakan untuk demplot termasuk lahan sawah tadah hujan, yang belum memiliki saluran irigasi dan drainase yang baik. Kawasan lahannya masih banyak tunggultunggul kayu bekas tebangan yang belum melapuk karena lahan relaif baru dibuka.

Tanah di rawa lebak bukan merupakan endapan marin sehingga tidak mengandung pirit. Umumnya ada dua jenis tanah di lahan lebak, yaitu tanah gambut, dengan ketebalan lapisan gambut $>50 \mathrm{~cm}$, dan tanah mineral, dengan ketebalan lapisan gambut di permukaan $<50 \mathrm{~cm}$. Tanah mineral yang mempunyai lapisan gambut di permukaan $20-50 \mathrm{~cm}$ disebut tanah mineral bergambut. Tanah mineral murni hanya memiliki lapisan gambut di permukaan <20 cm (Subagyo, 2006).

Kendala utama pengembangan lahan rawa lebak adalah genangan maupun kekeringan yang belum dapat diperediksi, tergantung pada keadaan hidrotopografi, curah hujan serta ketinggian air sungai setempat. Selain tata air, kendala lain yang dijumpai adalah sistem budidaya yang dilakukan petani masih belum optimal karena sebelumnya mata pencaharian utama petani adalah nelayan.

\section{Sifat Fisik dan Kimia Lahan Pengkajian}

Hasil analisis status hara tanah dan sifat fisik lahan yang digunakan sebagai demplot disajikan pada Tabel 1 dan 2 . 
Tabel 1. Sifat Kimia Tanah pada Lahan Pengkajian

\begin{tabular}{llcccc}
\hline No & Desa, Kecamatan & pH & \multicolumn{3}{c}{ Status Hara } \\
\cline { 3 - 5 } & & & $\mathrm{N}$ & $\mathrm{P}$ & $\mathrm{K}$ \\
\hline $\mathbf{1}$ & Panggak Darat, Lingga & $4,5-6,0$ & rendah-sedang & sedang & rendah \\
$\mathbf{2}$ & Panggak Laut, Lingga & $3.0-4.0$ & rendah-sedang & sedang & rendah \\
$\mathbf{3}$ & Narekeh, Lingga & $5.0-6.0$ & rendah-sedang & sedang & rendah \\
$\mathbf{4}$ & Bukit Langkap, & $5.0-6.0$ & sedang & sedang-tinggi & rendah \\
& Lingga Timur & & & & \\
$\mathbf{5}$ & Sungai Besar, & $4.5-5.5$ & rendah & rendah & rendah \\
& Lingga Utara & & & & \\
\hline
\end{tabular}

Tabel 2. Sifat Fisik Tanah pada Lahan Pengkajian

\begin{tabular}{|c|c|c|c|}
\hline \multirow[t]{2}{*}{ No } & \multirow[t]{2}{*}{ Desa, Kecamatan } & \multicolumn{2}{|r|}{ Sifat Fisika } \\
\hline & & Tekstur & Warna \\
\hline 1 & Panggak Darat, Lingga & Lempung Berpasir & $\begin{array}{c}5 \text { YR 3/2 - } 10 \text { YR 4/3 } \\
\text { (Coklat tua kemerahan - Coklat tua) }\end{array}$ \\
\hline 2 & Panggak Laut, Lingga & Lempung & $\begin{array}{c}10 \mathrm{R} 2.5 / 2 \\
\text { (merah sangat gelap) }\end{array}$ \\
\hline 3 & Narekeh, Lingga & Lempung & $\begin{array}{c}10 \mathrm{YR} 2 / 2 \\
\text { (Coklat tua sangat gelap) }\end{array}$ \\
\hline 4 & $\begin{array}{l}\text { Bukit Langkap, } \\
\text { Lingga Timur }\end{array}$ & Lempung Berpasir & $\begin{array}{c}10 \text { YR } 4 / 3 \\
\text { (Coklat hingga coklat tua) }\end{array}$ \\
\hline 5 & $\begin{array}{l}\text { Sungai Besar, } \\
\text { Lingga Utara }\end{array}$ & Lempung Berdebu & $\begin{array}{l}10 \text { YR } 3 / 3 \\
\text { (Coklat tua) }\end{array}$ \\
\hline
\end{tabular}

Tabel 1 di atas menunjukkan bahwa rata-rata derajat kemasaman tanah yang digunakan sebagai demplot pertanaman padi sawah tergolong masam hingga agak masam (4.5-6.0), bahkan lahan yang terletak di desa Panggak Laut, kec. Lingga memiliki $\mathrm{pH}$ yang sangat masam, yaitu 3.0-4.0. Tingkat kemasaman yang tinggi ini diantaranya disebabkan oleh kondisi drainase yang buruk dan terjadinya hidrolisis asam-asam organik. Kondisi $\mathrm{pH}$ yang rendah ini secara tidak langsung akan menghambat ketersediaan unsur hara bagi tanaman. Hal ini terjadi karena adanya antagonis unsur hara, dimana unsur mikro yang dominan seperti $\mathrm{Al}$ dan $\mathrm{Fe}$ akan mengikat unsur $\mathrm{P}$ dan $\mathrm{K}$. Oleh karenanya terjadi defisiensi unsur hara $\mathrm{P}$ dan $\mathrm{K}$ yang mengakibatkan tanaman tidak dapat berproduksi dengan optimal, diantaranya menyebabkan perakaran tanaman terganggu, jumlah anakan rendah, hingga terjadinya gabah hampa.

Untuk memperbaiki kualitas lahan rawa dan menjamin pertumbuhan tanaman lebih optimal di lahan tersebut, tindakan pengapuran dan pemupukan perlu dilakukan. 69 | Jurnal Agriekstensia Vol. 18 No. 1 Juli 2019
Berdasarkan hasil uji menggunakan PUTR, rekomendasi kapur dan pupuk yang diberikan pada lokasi demplot sebesar 0.51.5 ton/ha kapur pertanian yang aplikasinya dilakukan pada saat pengolahan lahan, 200$300 \mathrm{~kg} / \mathrm{ha} \mathrm{N}$-Urea yang diaplikasikan $1 / 3$ saat awal tanam, $1 / 3$ saat 2-3 MST dan $1 / 3$ saat $4-5$ MST, $150 \mathrm{~kg} / \mathrm{ha} \mathrm{K-KCl}$, serta $100 \mathrm{~kg} / \mathrm{ha} \mathrm{P}-$ SP-36 yang diberikan sebagai pupuk dasar. Upaya lain yang dapat ditempuh untuk menetralisir $\mathrm{pH}$ tanah agar padi dapat beradaptasi dan tumbuh dengan baik adalah dengan mengurangi kandungan unsur $\mathrm{Al}$ dan Fe tersedia melalui pencucian lewat perbaikan drainase (Helmi, 2015).

Sebagian gambut yang terdapat di rawa lebak dalam mempunyai tingkat dekomposisi hemik, dengan warnanya relatif sama, yaitu cokelat sangat gelap atau hitam. Dalam klasifikasi Taksonomi Tanah (Soil Survey Staff, 1999 dalam Subagyo, 2006), tanah-tanah tersebut termasuk ke dalam ordo Histosols, sedangkan tanah mineral pada lahan lebak termasuk ordo Entisols dan Inceptisols. Oleh karena termasuk "lahan basah" (wetland), maka tergolong dalam 
subordo Aquents dan Aquepts. Tanah-tanah mineral yang tergolong lebak dangkal termasuk Inceptisols basah, subgrup Epiaquepts dan Endoaquepts, dan sebagian Entisols basah yaitu Fluvaquents. Pada lebak tengahan, yang dominan adalah Entisols basah, yakni Hydraquents.

\section{Pertumbuhan dan Hasil Tanaman Padi}

Untuk pembukaan lahan sawah baru diperlukan beberapa persyaratan teknis dan non teknis. Persyaratan teknis meliputi: (1) topografi, (2) iklim, (3) karakteristik tanah, (4) potensi banjir, (5) slinitas dan alkalinitas, serta (6) status penggunaan lahan (Ritung dan Suharta, 2010). Tanaman padi dapat hidup baik di daerah yang berhawa panas dan banyak mengandung uap air. Curah hujan yang dikehendaki per tahun sekitar 1500-2000 mm, dengan distribusi selama 4 bulan. Suhu yang baik untuk pertumbuhan tanaman padi sekitar $23{ }^{\circ} \mathrm{C}$. Ketinggian tempat yang cocok untuk tanaman ini berkisar antara 0-1500 mdpl. Tanah yang sesuai untuk pertumbuhan tanaman padi adalah tanah sawah yang memiliki kandungan fraksi pasir, debu dan lempung dalam perbandingan tertentu dengan jumlah air yang cukup. Padi dapat tumbuh dengan baik pada tanah yang ketebalan lapisan atasnya antara $18-22 \mathrm{~cm}$ dengan $\mathrm{pH}$ antara 4 -7 (Helmi, 2015).

Pengembangan pertanian di lahan rawa, khususnya tanaman padi, sering menghadapi kendala seperti: (1) genangan air dan kondisi fisik lahan, (2) kemasaman tanah tinggi, (3) ketersediaan unsur hara menurun dan pada kondisi tereduksi sering muncul keracunan besi ferro $\left(\mathrm{Fe}^{2+}\right)$, dihidrogen sulfida $\left(\mathrm{H}_{2} \mathrm{~S}\right)$, karbon dioksida $\left(\mathrm{CO}_{2}\right)$, dan asam-asam organik (Alwi, 2014).

Varietas padi yang digunakan dalam kajian adalah INPARA 5. Varietas ini dipilih karena merupakan varietas padi pasang surut/ lebak. Secara umum deskripsi varietas ini adalah: (1) umur tanaman 115 hari, (2) anakan produktif 18 batang, (3) jumlah gabah per malai 102 butir, (4) rata-rata hasil $4.45 \mathrm{t} / \mathrm{ha}$ dengan potensi hasil $7.2 \mathrm{t} / \mathrm{ha}$, (5) agak tahan terhadap WCK Biotipe 3 dan 70 | Jurnal Agriekstensia Vol. 18 No. 1 Juli 2019 tahan terhadap HDB strain IV dan VIII, serta (6) toleran terendam selama 14 hari pada fase vegetatif. Varietas ini dianjurkan ditanam di daerah rawa lebak dangkal dan sawah rawan banjir (Balitbangtan, 2009).

Hasil panen padi pada demplot di ketiga kecamatan disajikan pada Grafik 1 berikut:

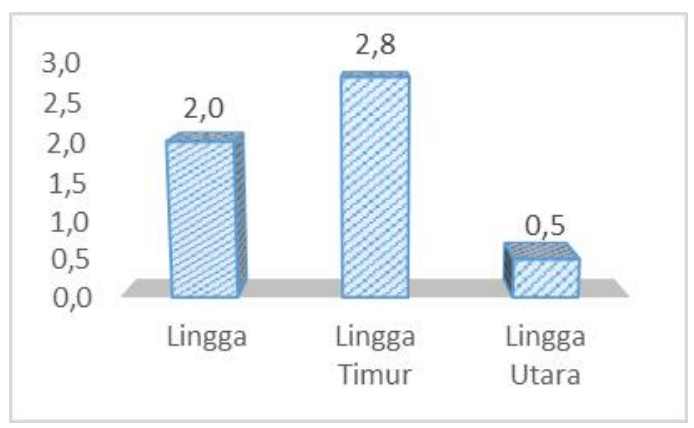

Gambar 1. Rata-rata Produksi Padi (ton/Ha)

Dari gambar di atas diketahui bahwa rata-rata hasil panen tertinggi diperoleh dari demplot yang terdapat di desa Bukit Langkap, kec. Lingga Timur. Hal ini menunjukkan bahwa produktivitas lahan rawa sangat beragam dan tergantung pada kondisi tanah, tata air serta penerapan teknologi terutama teknologi pengeloaan lahan dan varietas yang ditanam. Dari hasil analisis sebelumnya, terlihat bahwa sifat kimia tanah di wilayah tersebut lebih baik dibandingkan dua kecamatan lainnya, yang ditandai dengan nilai $\mathrm{pH}$ yang masammendekati netral dan status hara $\mathrm{N}$ dan $\mathrm{P}$ yang bernilai sedang-tinggi. Tentunya kondisi tersebut turut mendukung bagi pertumbuhan dan perkembangan tanaman padi.

Selain faktor karakteristik tanah, faktor genetik dari varietas yang digunakan juga dapat mempengaruhi produktivitas tanaman. Berdasarkan hasil penelitian Helmi (2015), didapatkan bahwa hasil produksi gabah kering panen (GKP) varietas Inpara 5 sebesar 2.5 ton/ha, dimana nilai tersebut lebih rendah dibandingkan dengan hasil panen varietas Inpara 1, Inpara 2, dan Inpara 3 yang rata-rata produksinya mencapai 4.3 ton/ha. Ketiga varietas tersebut dimungkinkan mempunyai daya adaptasi/ 
toleransi dan potensi hasilnya tinggi. Oleh karena itu, varietas-varietas ini dapat dijadikan sebagai peluang baru sebagai pilihan bagi petani untuk dibudidayakan di lahan sawah rawa lebak.

Peningkatan produksi pada lahan spesifik dapat membantu distribusi pengembangan suatu varietas pada lingkungan tertentu dan sekaligus mendukung pelestarian swasembada beras. Selain itu hasil gabah dipengaruhi oleh jumlah anakan yang terdapat pada tanaman. Sesuai dengan pernyataan Lakitan (1993) dalam Helmi (2015) melaporkan bahwa kemampuan pembentukan anakan produktif merupakan hal yang penting dalam penentuan perolehan hasil gabah dan juga hal ini sangat erat kaitannya terhadap jumlah gabah permalai.

Lahan rawa jika dikembangkan sebagai lahan pertanian hendaknya menggunakan tiga pendekatan, yaitu: (1) menerapkan teknologi pengelolaan lahan berupa pengelolaan air, tanah, hara dan bahan amelioran; (2) menggunakan tanaman dan varietas toleran terhadap kondisi lahan dan preferensi petaninya; dan (3) memadukan keduanya secara serasi. Pendekatan yang pertama agak mahal dan lebih sulit karena memerlukan tambahan tenaga, sarana dan biaya tapi hasilnya baik. Sedangkan pendekatan yang kedua lebih mudah dan murah tapi hasilnya suboptimal. Pendekatan yang ketiga adalah alternatif terbaik karena selain dapat memperbaiki kualitas dan produktivitas lahan juga memberikan hasil yang optimal dengan biaya yang relatif lebih murah (Alihamsyah, 2002).

\section{Kendala Usahatani Padi dan Peluang Peningkatan Produksi Padi di Lahan Rawa Lebak}

Pengelolaan tanah dan air (soil and water management) merupakan kunci utama keberhasilan pengembangan pertanian di lahan rawa. Pengelolaan tanah dan air ini meliputi: jaringan tata air makro maupun mikro, penataan lahan, ameliorasi dan pemupukan. Tata air mikro berfungsi untuk:

71 | Jurnal Agriekstensia Vol. 18 No. 1 Juli 2019
(1) mencukupi kebutuhan evapotranspirasi tanaman, (2) mencegah pertumbuhan gulma pada pertanaman padi sawah, (3) mencegah terbentuknya bahan beracun bagi tanaman melalui penggelontoran dan pencucian, (4) mengatur tinggi muka air, dan (5) menjaga kualitas air di petakan lahan dan saluran. Sedangkan pengelolaan air pada saluran tersier bertujuan untuk: (1) memasukkan air irigasi, (2) mengatur tinggi muka air pada saluran dan petakan, dan (3) mengatur kualitas air dengan membuang bahan beracun yang terbentuk di petakan serta mencegah masuknya air asin ke petakan lahan (pada lahan rawa lebak marin) (Alwi, 2014). Tanpa pengelolaan yang baik, masalah air juga menjadi kendala di lahan rawa lebak dangkal. Menurut Guswara dan Widyantoro (2012) dalam Pujiharti (2017), masalah ini sulit diatasi petani secara individu, karena kelebihan air atau kekeringan tidak hanya terjadi pada lahan individu, tetapi dalam satu hamparan sehingga peran Pemerintah Daerah sangat diharapkan untuk mengatur tata air di lahan rawa lebak.

Pengelolaan hara spesifik lokasi juga menjadi kendala dalam upaya peningkatan produksi padi karena petani menggunakan pupuk tidak berdasarkan ketersediaan hara tanah dan kebutuhan tanaman, tetapi berdasarkan kemampuan ekonomi petani. Salah satu upaya yang mungkin dapat dilakukan adalah dengan penyediaan alat pengukur hara tanah rawa (PUTR) di lapangan yang dimiliki oleh Dinas Pertanian setempat. Demikian pula bagan warna daun (BWD) untuk mengontrol kebutuhan pupuk nitrogen tanaman.

Penggenangan dan pengeringan tanah menyebabkan perubahan beberapa sifat kimia tanah antara lain: peningkatan $\mathrm{pH}$ tanah, ketersediaan $\mathrm{P}$ meningkat, dan kadar $\mathrm{Fe}^{2+}$ makin berkurang. Perubahan sifat kimia tersebut berpengaruh positif terhadap pertumbuhan tanaman padi. Takahashi (1999) dalam Alwi (2014) menyatakan bahwa pengeringan menyebabkan oksida besi ferri secara bertahap terkeristalisasi menjadi bentuk besi yang kurang reaktif. 
Penggenangan berkala merupakan cara yang paling efektif untuk menghilangkan pengaruh buruk yang timbul akibat penggenagan seperti: akumulasi $\mathrm{CO}_{2}, \mathrm{H}_{2} \mathrm{~S}$, asam-asam organik, $\mathrm{Fe}$, dan Mn tereduksi. Kondisi oksidasi dan reduksi secara bergantian dalam tanah dapat menyebabkan penambahan senyawa-senyawa besi ferro.

Selain air dan hara, pengembangan pertanian di lahan rawa lebak juga terkendala dengan adanya gangguan organisme penggagu tanaman (OPT), diantaranya hama tikus, wereng cokelat, penggerek batang, dan penyakit blast. Menurut Djamhari (2009), kendala tersebut dapat diatasi dengan penerapan teknologi pengelolan air dan pengelolaan hama dan penyakit secara terpadu (PHT). PHT merupakan pengelolaan hama secara ekologis, teknologis, dan multidisiplin dengan memanfaatkan berbagai taktik pengendalian yang kompatibel dalam satu kesatuan koordinasi sistem pengelolaan pertanian berwawasan lingkungan dan berkelanjutan. Pendekatan ini meliputi kombinasi pengendalian hayati, kultur teknis, dan pemakaian bahan kimia secara bijaksana.

Kehilangan hasil juga dapat menjadi kendala tersendiri pada usaha tani padi. Tjahjohutomo (2008) dalam Iswari (2012) menyatakan bahwa penanganan panen secara konvensional menyebabkan susut hasil $21.1 \%$. Bila penanganan panen dan pascapanen tersebut dimodifikasi, yaitu penggunaan sabit diganti dengan reaper, perontokan gabah dengan cara gebot diganti dengan power thresher, pengeringan gabah di lantai jemur diganti dengan flat bed dryer, dan penggilingan gabah dengan husker, maka susut hasil menurun menjadi $13 \%$. Penerapan inovasi pada semua tahapan budi daya padi berpeluang meningkatkan produksi menuju swasembada beras berkelanjutan.

Kendala sosial ekonomi juga ditemui pada usaha tani pada rawa lebak, seperti keterbatasan modal, tenaga kerja, dan tingkat pendidikan petani yang masih rendah. Oleh karena itu, pendampingan oleh penyuluh, 72 | Jurnal Agriekstensia Vol. 18 No. 1 Juli 2019 pelatihan atau sekolah lapang (SL), pembentukan dan penguatan kelembagaan petani perlu dilakukan. Hal ini tentunya diperlukan peran serta dari seluruh stakeholder.

\section{KESIMPULAN}

Kesimpulan yang diperoleh dari hasil pengkajian ini adalah:

1. Kendala utama pengembangan lahan rawa lebak adalah genangan maupun kekeringan yang belum dapat diperediksi dan reaksi tanah yang bersifat sangat masam-masam, serta status hara yang tergolong rendah-sedang.

2. Hasil panen menggunakan varietas Inpara 5 masih tergolong rendah, sekitar 0.5 2.5 ton/ha.

3. Produksi padi pada lahan rawa lebak masih berpeluang untuk dikembangkan dan ditingkatkan dengan melalui penerapan teknologi spesifik lokasi, terutama inovasi pengelolaan air, hara dan tanaman secara terpadu.

\section{DAFTAR PUSTAKA}

Alihamsyah, T. 2002. Optimalisasi Pendayagunaan Lahan Rawa Pasang Surut. In Seminar Nasional "Optimalisasi Pendayagunaan Sumberdaya Lahan".

Alwi, M. 2014. Prospek Lahan Rawa Pasang Surut Untuk Tanaman Padi. In Prosiding Seminar Nasional "Inovasi Teknologi Pertanian Spesifik Lokasi".

Arsyad, D. M., B. B. Saidi, dan Enrizal. 2014. Pengembangan Inovasi Pertanian di Lahan Rawa Pasang Surut Mendukung Kedaulatan Pangan. In Jurnal Pengembangan Inovasi Pertanian Vol. 7 No. 4.

BPS Kab. Lingga. 2017. Kabupaten Lingga Dalam Angka. 
Djamhari, S. 2009. Peningkatan Produksi Padi di Lahan Lebak Sebagai Alternatif Dalam Pengembangan Lahan Pertanian ke Luar Pulau Jawa. In Jurnal Sains dan Teknologi Indonesia Vol 11 No.1.

Helmi. 2015. Peningkatan Produktivitas Padi Lahan Rawa Lebak Melalui Penggunaan Varietas Unggul Padi Rawa. In Jurnal Pertanian Tropik Vol. 2 No. 2.

Iswari, K. 2012. Kesiapan Teknologi Panen dan Pascapanen Padi Dalam Menekan Kehilangan Hasil dan Meningkatkan Mutu Beras. In Jurnal Litbang Pertanian Vol. 31 No. 2.

Kurniawan, A. 2015. Melongok Program Kerja Kementan 2015 dan Dukungan Pendanaannya. In Sinar Tani Edisi 4-10 No. 3593.

Pujiharti, Y. 2017. Peluang Peningkatan Produksi Padi di Lahan Rawa Lebak Lampung. In Jurnal Litbang Pertanian Vol. 36 No. 1.

Ritung, S. dan N. Suharta. 2010. Sebaran dan Potensi Pengembangan Lahan Sawah Bukaan Baru. In F. Agus, Wahyunto, dan D. Santoso (Eds.). Tanah Sawah Bukaan Baru. Balai Besar Penelitian dan Pengembangan Sumberdaya Lahan Pertanian, Bogor.

Suharta, N. 2010. Karakteristik dan Permasalahan Tanah Marginal dari Batuan Sedimen Masam di Kalimantan. In Jurnal Litbang Pertanian Vol. 29 No. 4.

Subagyo, H. 2006. Lahan Rawa Lebak. In Didi Ardi S., U. Kurnia, Mamat H.S, W. Hartati, dan D. Setyorini (Eds.). Karakteristik dan Pengelolaan Lahan Rawa. Balai Besar Penelitian dan Pengembangan Sumberdaya Lahan Pertanian, Bogor.

73 | Jurnal Agriekstensia Vol. 18 No. 1 Juli 2019 